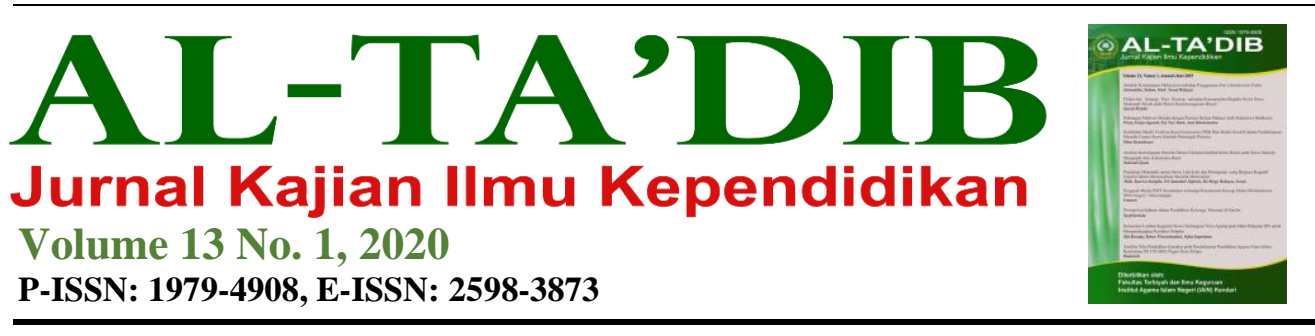

\title{
The Implementation of Communicative Language Teaching (CLT) and Factors Hindering Teachers from Implementing it in High School
}

\author{
Afnesha Noveriana Chang ${ }^{1}$, Suparmi ${ }^{2}$ \\ ${ }^{1}$ Universitas Putra Indonesia, Padang, Indonesia. E-mail: afneshanoveriana_chang@upiyptk.ac.id \\ ${ }^{2}$ Universitas Putra Indonesia, Padang, Indonesia. E-mail: suparmi@ upiyptk.ac.id
}

\begin{tabular}{l} 
INFORMASI ARTIKEL \\
\hline Kata Kunci: \\
implementasi; pendekatan \\
pengajaran; pengajaran \\
bahasa komunikatif; \\
sekolah menengah \\
Cara Mensitasi: \\
Chang, A. N., \& Suparmi. \\
(2020). The \\
implementation of \\
communicative language \\
teaching (CLT) and factors \\
hindering teachers from \\
implementing it in high \\
school. Al-Ta'dib, 13(1), \\
46-56 \\
DOI:
\end{tabular}

\begin{abstract}
ABSTRAK
Penelitian ini bertujuan untuk melihat implementasi pengajaran bahasa komunikatif (CLT) dan menginvestigasi factor-faktor yang menghambat para guru dalam melaksanakannya. Data dikumpulkan melalui angket online dan wawancara terhadap 29 guru sekolah menengah atas in Padang, Indonesia. Hasil penelitian mengungkapkan bahwa sebagian besar guru paham konsep CLT dengan baik. Akan tetapi, mereka mengalami berbagai hambatan dalam pelaksanaannya. Guru kurang memiliki akses terhadap budaya bahasa target, kurang waktu untuk mengembangkan materi, dan kurang keterlibatan dalam pelatihan yang bisa membantu mereka memperbaiki kemampuan mengajarnya. Penelitian ini mengindikasikan perlunya penelitian guna melihat bagaimana CLT ini dapat ditingkatkan dalam konteks pengajaran di Indonesia.
\end{abstract}




\begin{tabular}{l} 
ARTICLE INFO \\
\hline Keywords: \\
Communicative language \\
teaching; high school; \\
implementation; teaching \\
approach \\
How to cite: \\
Chang, A. N., \& Suparmi. \\
(2020). The \\
implementation of \\
communicative language \\
teaching (CLT) and factors \\
hindering teachers from \\
implementing it in high \\
school. Al-Ta'dib, 13(1), \\
46-56 \\
DOI:
\end{tabular}

\begin{abstract}
This study attempts to see the implementation of communicative language teaching and to investigate factors hindering high school teachers from implementing it. Data were collected using online questionnaire and interview. This questionnaire was administered to 29 senior high school teachers. The findings show that most teachers understand the concept of CLT well. However, there are some obstacles that they need to deal with in implementing CLT the classroom. Teachers experience limited access to the target language's culture, limited time to develop materials for CLT and lack of training in order to improve their teaching skill. Given its importance, more research is still needed to see how this CLT method can be improved in Indonesia teaching context in the future.
\end{abstract}

\section{Introduction}

Communicative language teaching (CLT) has become a new alternative responding to the traditional approach which is well known as grammar translation based. However, CLT implementation has never been easy. Both teachers and students mostly find challenges in regards to the teaching model, teaching material, students' participation and many others. Some studies have been conducted to analyze these challenges. Research done by Rahmawati (2019) revealed that teachers have several issues like the students' low motivations, the teachers' role, the class size, the teachers' income, and the availability of English materials.

Regardless those described challenges above, CLT is viewed as a "very grounded principles in the notion of communicative competence as the goal of second language teaching" (Richards, 2006, p. 22). Richards (2006) and Littlewood (1981) also added that communicative competence can be understood as goals of language teaching. It is also seen as a way of learning language and choices of tasks that could facilitate learning well. CLT has been broadly implemented as a response to the old approach like audiolingual and grammar-based approach that focuses more on the mastery of grammatical rules. In addition, Nunan (2004) agrees that learning language is more than just the act of memorizing grammatical rules and vocabularies. However, it is believed as a process of creating meaning from what is provided by the 
language. To make the learning meaningful, the best approach that could be applied is the communicative language teaching approach. In CLT, learning is no longer seen merely as a process of habit formation. Besides, learners and their cognitive process are not seen as a complex learning process (Nunan, 2004). Nunan also argues that rather than just being seen as a set of phonological, lexical and grammatical items to be remembered, language can be taught of as a communication tool. Therefore, the goal of the language learning, later on, is not merely knowing the grammatical rules but also knowing what to do with the grammatical rules.

Nowadays, the demand on active English, as the most widely spoken language among global society, has been rising for the last few years. As the world is getting more borderless, the needs on communicative competence in English is getting bigger, too. This is in line with Radzi, Azmin, Zolhani, and Latif (2007) who stated that English is an important and crucial medium of communication among people in both intra-national or international levels. To confirm this, Richards (2006) also explains that a huge demand for good communication skills in English is needed in society around the world. This thing, at the end, also affects the learning outcomes that is expected from English subject at school. After finishing the English lesson, students are not merely required to master English rules but also putting the rules into practice. The learning method that suit this learning target is known to be communicative language teaching (CLT).

Richards (2001) said that CLT is a communicative approach which aims is to develop learners' communicative competence. Communicative competence, in this case, is considered to be the primary conception of CLT. Nowadays, many scholars on ELT have been working seriously until they finally find CLT which accommodates society demand regarding English speaking competent. This method is regarded as the response to the traditional method that focused on the mastering the language rules only. CLT advocates teaching practices that develop communicative competence in authentic contexts (Larsen-Freeman, 2000).

However, it is notable that the theories and practices of CLT have faced various challenges in EFL contexts (Anderson, 1993; Ellis, 1996). English teachers in Indonesia has encountered many problems that hinder them from implanting CLT in their teaching context. According to Li (1998), there are four categories that influence the implementation of CLT. They are teachers, students, the educational system, and the CLT itself. Meanwhile, in this research, the research limits the focus of the study into two categories only: students and teachers. Few studies have been conducted to analyze the student and teacher aspect in CLT in senior high school context. For this reason, it is 
worthwhile to conduct study on the implementation of CLT in senior high schools. This study contributes to see what actions might be taken to improve the implementation of CLT in Indonesian EFL instructional context in the future.

\section{Method}

This qualitative research was carried out by using a set of instruments, i.e. online questionnaire and online interview with 29 participants (male and female) from several senior high schools and several backgrounds. Some of them come from public schools and some others come from private schools. The location of the schools is also varied. Some are located in rural area and some are in urban area. The participants were chosen randomly from different senior high schools in Padang, West Sumatera. The online questionnaire consists of some questions investigating about the teachers' demographic as well as teachers' difficulties in implementing CLT in their classrooms. The questions required close-ended answers (in scales) and open-ended answers in short paragraph. Nunan (1999) said that close-ended questions enable the participants to accurately reflect what they want to convey while the openended ones let them to explain their answers in a more detailed way. Having the questionnaire administered to the participants, online interview was arranged in order to confirm information gained from the questionnaire. Eight participants agreed to be interviewed and they gave different views about the condition and the implementation of communicative language teaching in their classrooms. The teachers provided further confirmation toward their CLT experience as resembled in the questionnaire.

The participants were interviewed individually through voice call and video call platform. The teachers gave constructive feedback for the betterment of CLT implementation in the future. The interview was carried out to teachers who were willing to participate voluntarily in the interview session in order to provide more elaboration on what they have chosen in the questionnaire. There was no specific time limit for the interview and the language used was mixed between English and Indonesian. The interview process was voice recorded and the answers were then translated and transcribed for further analysis by the researcher. All participants' names are pseudonyms.

\section{Findings and Discussion}

The findings of this research shows some problems coming from the teachers' side. The result of questionnaire shows that from 29 participants 
participated on the research, $66.5 \%$ of them hold bachelor degree with less than five years teaching experience. Then, the majority of the teachers work in public school in big cities. The participants are commonly responsible for 1 to 12 classes with average teaching hour around 17 hours per week. This different workload, later on, lead to different result as well. The heavier the workload, the harder the teacher maximize their teaching performance in the classroom. Moreover, interestingly, 50\% of the teachers still need to accommodate big classroom with number of students ranging from 30-39 students in a class. This condition hinders the teachers from practicing CLT in their classroom since CLT requires them to pay attention to each sudent personally. This is in line with Rahmawati's (2019) argument that big class situation influences the teachers' choices of activity to apply in their classrooms. She also added that the condition makes it hard for teachers to monitor the whole class while studying. Dardjowidjojo (1997) calls this a "pragmatic constraint" where big classes can restrict teachers from performing well in the classroom. Following are explanations taken from questionnaire and interview.

\subsection{Teachers' Perspective towards CLT}

When asking to describe CLT in their own words, teachers came up with several explanations about their comprehension regarding CLT. A teacher named Lita stated that "CLT is an approach in teaching learning foreign language that stresses interaction, both in process and the purpose of learning". Another teacher also said that "CLT is a way to support students learning by encouraging them to always communicate. It is not teachercentered, but it is a student-centered". These answers from the teachers reveal that they have proper knowledge about what CLT is. This finding is similar to Christianto's (2019) study that teachers mostly aware that CLT is a good approach to be used in the teaching and learning process.

Table 1 shows that the majority of the participants have proper background about CLT. The results are ranging from $67.9 \%$ up to $92.9 \%$. The teachers are aware that CLT method relies on teaching conversation, emphasizes fluency over accuracy, glorifies open-ended discussion, and involves a lot of group work rather than individual work. Moreover, they are also aware that language learning intertwined with culture learning as well. Ali, Kazemian, and Mahar (2015) argue that language learning process require both practicing linguistic forms and becoming familiar with the target language culture in order to totally make sense certain language. 


\section{Table 1. Teachers' perspective towards CLT in general}

\begin{tabular}{|c|c|c|c|c|}
\hline No. & Questions & Yes & No & Not Sure \\
\hline 1. & $\begin{array}{l}\text { CLT relies heavily on teaching } \\
\text { conversation }\end{array}$ & $67.9 \%$ & $14.3 \%$ & $17.9 \%$ \\
\hline 2. & CLT emphasizes fluency over accuracy & $78.6 \%$ & $10.7 \%$ & $10.7 \%$ \\
\hline 3. & $\begin{array}{l}\text { CLT means the absence of grammar in a } \\
\text { course }\end{array}$ & $15.4 \%$ & $57.7 \%$ & $26.9 \%$ \\
\hline 4. & $\begin{array}{l}\text { CLT pays greater attention to open- } \\
\text { ended discussion activities as the main } \\
\text { feature of the course }\end{array}$ & $78.6 \%$ & $3.6 \%$ & $17.9 \%$ \\
\hline 5. & CLT involves no grammar teaching & $7.1 \%$ & $75 \%$ & $17.9 \%$ \\
\hline 6. & CLT involves a lot of group work & $81.5 \%$ & $7.4 \%$ & $11.1 \%$ \\
\hline 7. & $\begin{array}{l}\text { CLT involves teaching of culture of the } \\
\text { target language }\end{array}$ & $78.6 \%$ & $7.1 \%$ & $14.3 \%$ \\
\hline 8. & CLT is a student-centered approach & $78.6 \%$ & $10.7 \%$ & $10.7 \%$ \\
\hline 9. & $\begin{array}{l}\text { CLT only concerns with teaching } \\
\text { speaking }\end{array}$ & $28.6 \%$ & $53.6 \%$ & $17.9 \%$ \\
\hline 10. & $\begin{array}{l}\text { CLT gives less importance to reading } \\
\text { and writing }\end{array}$ & $14.3 \%$ & $50 \%$ & $35.7 \%$ \\
\hline 11. & $\begin{array}{l}\text { CLT goal is to enable learners to } \\
\text { communicate with the target language }\end{array}$ & $92.9 \%$ & $7.1 \%$ & $0 \%$ \\
\hline
\end{tabular}

In CLT, learning the target language culture will make the learning process more engaging and more interesting at the same time. Teachers will also have good perspective on the classroom activities where the center relies heavily on students, not on the teachers. In terms of defining, most of the participants have good understanding about it. Rika, a newbie English teacher, explained that CLT is a collaborative learning in which students have to work together to achieve the ability to communicate in target language. Thus, from the explanations above, it can be assumed that the participants have good perception towards CLT.

Most of the time when people come across to CLT term, they assume that the learning outcomes only focus on speaking and ignore the existence of grammar in it. However, in this research, teachers agreed that learning grammar cannot be separated from learning CLT. As one of the participants reveals in the following extract.

"I think the CLT learning focuses on communicative competence, but it cannot ignore the grammar learning process. Grammar still exists, but in communicative way. The better a student can comprehend grammar, the better he or she can communicate actively..." (Mona, Interview, August $1^{\text {st }}, 2019$ )

Thus, the teachers also agree that CLT does not necessarily mean that the learning process only focus on speaking and give less attention to reading, 
listening and writing since CLT takes all skills to gain good communicative competence. This is also confirmed by a participant, Ana, who agreed that CLT is not only about speaking but also other three skills supporting each other. The finding of this study reflect that teachers have proper knowledge about CLT and about how it should be run in the classroom. Moreover, data of this study indicate that the teachers are also aware that the final goal of CLT is to enable learners to communicate with the target language effectively.

\subsection{Challenges in Implementing CLT in Indonesian Teaching Context}

In practice, some teachers find it difficult to implement CLT in their classroom due to several reasons. First and foremost, teachers have limited knowledge about the appropriate use of the method. This is where they know about the characteristics of CLT in brief, but they face difficulties to implement it. The teachers find out some difficulties when it comes to putting the theory into practice in the classroom. Secondly, teachers have limited access to the target language culture. They cannot access and cannot directly see how the language is really used by the native speakers. Thus, they cannot get the real model on how the language is supposed to be spoken effectively. One of the participants stated that they have difficulties to access the target language's culture and ended up focusing bringing local culture to the classroom. Teachers' challenge in implementing CLT in accessing the target language is described in the following Figure 1.

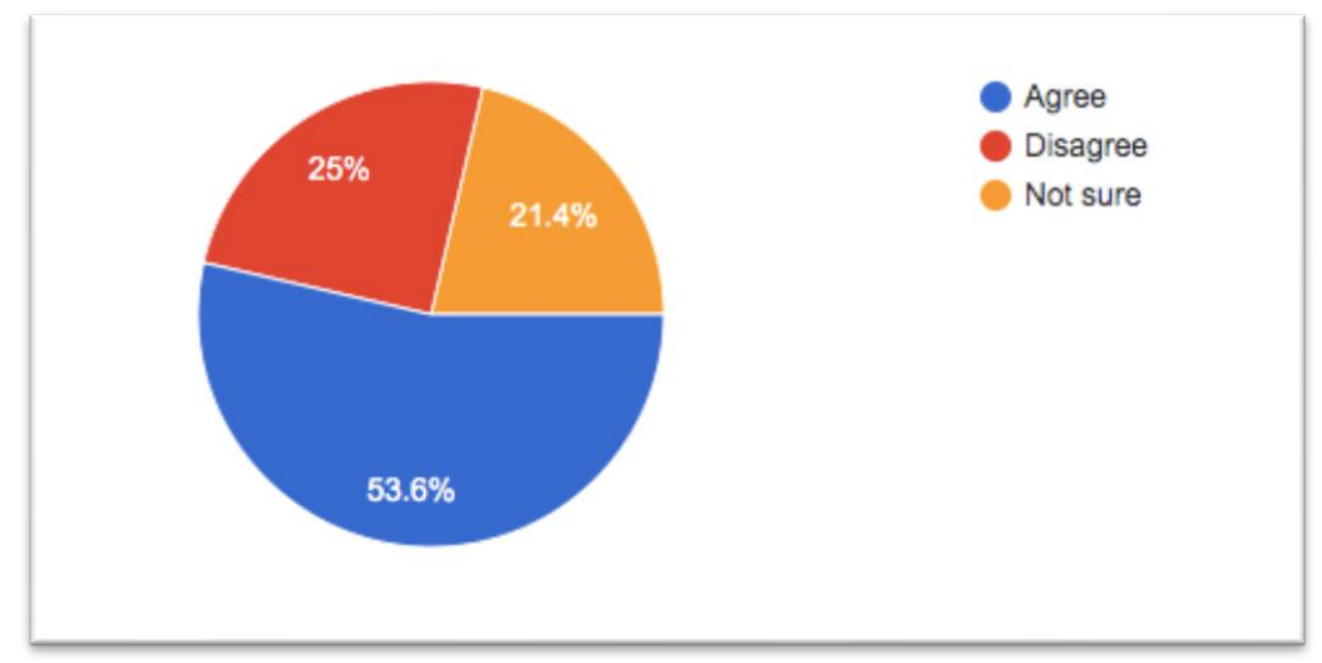

Figure 1. Teachers' limited access to the target language's culture

The third question answered by the participants was related to the time availability to prepare the material for communicative classes. In the interview session, a teacher confirmed this point by telling the researcher that she had a 
lot of related to the administrative workload so she does not have enough time to develop, explore and implement communicative materials to the classroom. At the end, the teachers just focus on the textbook making the learning becomes teacher-centered and the communicative competence becomes even harder to achieve. This situation was confirmed by $78.6 \%$ of the participants. Then, as mentioned above, teachers have heavy workload that hinder them to develop their teaching materials and activities into the communicative ones. This indirectly affects the teachers' readiness to run the classroom. Some teachers, through the interview, clarified that they tend to switch the focus into academic competence rather than communicative competence.

In terms of students' aspect, data from interview indicate that teachers acknowledge most students are shy and not willing to participate in the communicative activities. The finding confirmed data from questionnaire that that $63 \%$ of teachers agreed that they experience this situation in their classrooms and only $18.5 \%$ who do not go with this finding as reflected in the following Figure 2.

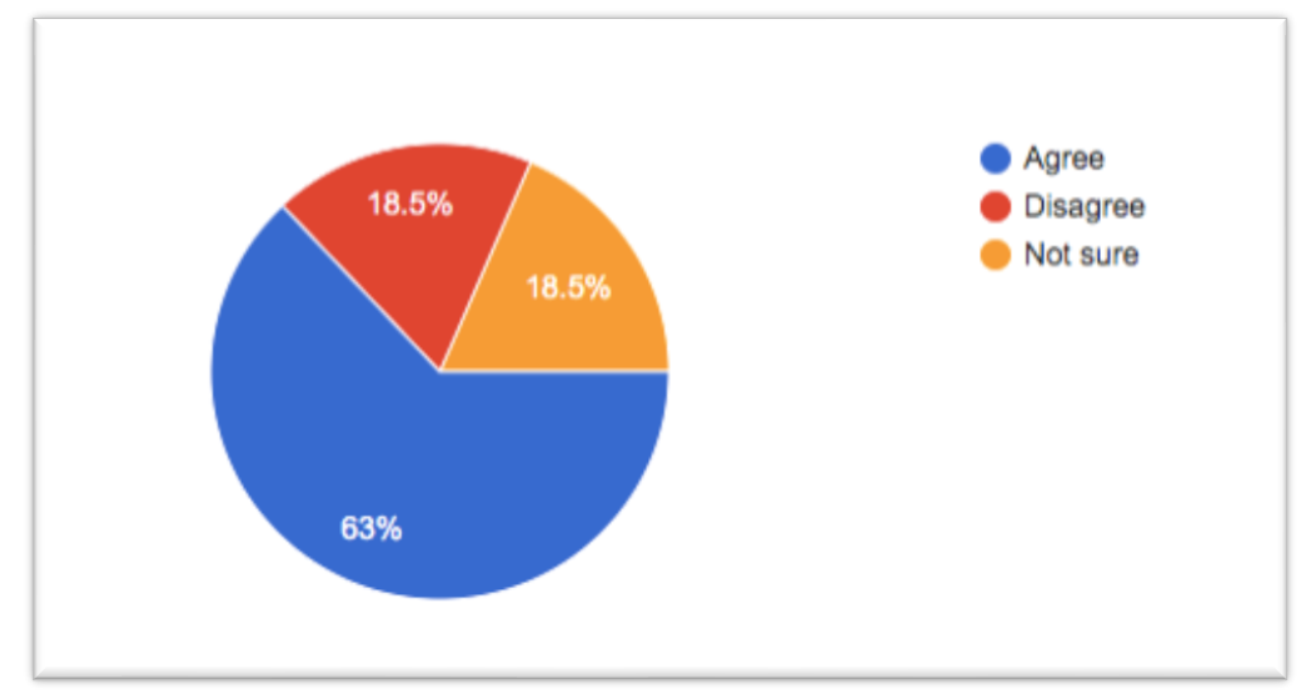

Figure 2. Students' lack of willingness to participate in class activities

The participants argue that in terms of CLT's implementation in the class, the students still have low motivation in learning English since they tend to neglect the teachers' instruction. Besides, the students' English proficiency is still low. Eight participants confirmed that students' low proficiency in English is the main barriers they faced in implementing CLT in their classroom. This is also considered as one of the constraints to effective CLT practice. Moreover, five teachers reported that test-oriented teaching has been one of the factors that influence students' motivation in learning English. The 
teachers acknowledged that this condition makes the CLT becomes harder to be implemented.

Data from interview revealed that the teachers acknowledged teacher professional training as an important factor in promoting the implementation of CLT. Due to the adoption of CLT in English curricula in Indonesia, CLT workshops have been offered by the government. The schools required them to attend teaching methodology conferences and workshops but not all of them could participate. Among eight interviewees, only four teachers claimed that teachers professional training helped them to understand the theoretical bases of CLT. Meanwhile, the other five teachers claimed that they get nothing but general knowledge from the training as one of the participants expressed in the following excerpt.

"As a teacher, I got training but only teacher education training in general. The government gave training to us to become a good teacher, not about the implementation of communicative language teaching in our classrooms... just the general one. It's been conducted for three times" (Nur, Interview, July $2^{\text {nd }}$, 2019)

The finding confirms that trainings for improving students' competence is still segmented to several schools only and do not equally distributed yet.

\section{Conclusion}

This study has highlighted some problems faced by English teachers in Padang, West Sumatera. The problems include the implementation of the CLT and factors that hinder teachers from implementing it in their teaching context. It is found that teachers actually have good understanding towards CLT but they face some obstacles when it comes to the implementation. The obstacles come from two aspects: a) teacher's side and b) students' side. The challenges faced by teachers are teachers limited knowledge about the appropriate use of CLT, teachers' limited access to the target language culture, inadequate time to develop materials for communicative classes, teachers' heavy workload and lack of time for material preparation. These obstacles are even more challenging by the obstacles coming from students' side. The teachers' revelation shows that students are having low confidence in English, not willing to participate in the classroom activities, lacking of motivation in learning, not willing to follow teachers' instruction and having low proficiency in English. After analyzing the obstacles, it is expected that teachers, students and the stakeholders can collaborate to find solution on this. Moreover, given the importance of this issue, it is hoped that other researchers may also conduct similar research in the future. 


\section{Acknowledgment}

The researcher is forever in debt with all the respondents who have participated in this research. The researcher would also like to thank Kemenristek Dikti for financially supporting this research through Penelitian Dosen Pemula (PDP) funding scheme of 2018/2019 academic year.

\section{References}

Ali, S., Kazemian, B., \& Mahar, I. (2015). The importance of culture in second and foreign language learning. Dinamika Ilmu, 15(1), 1-10.

Anderson, J. (1993). Is the communicative approach practical for teaching English in China? Pros and cons. System, 21(4), 417-480.

Christianto, D. (2019). Teachers' perceptions on the use of the communicative language teaching approach in the English classrooms. International Journal of Indonesian Education and Teaching, 3(1), 90-101.

Dardjowidjojo, S. (2002). Academic and non-academic constraints in the teaching of English in Indonesia. Bahasa, Pendidikan, dan Agama, 65, 117-132.

Ellis, G. (1996). How culturally appropriate is the communicative approach? ELT Journal, 50(3), 213-218.

Larsen-Freeman, D. (2000). Techniques and principles in language teaching. Oxford: Oxford University Press.

Li, D. (1998). It's always more difficult than you plan and imagine: Teachers' perceived difficulties in introducing the communicative approach in South Korea. TESOL Quarterly, 32(4), 677-703.

Littlewood, W. (1981). Communicative language teaching. Cambridge: Cambridge University Press.

Nunan, D. (1999). Research methods in language learning. Cambridge: Cambridge University Press.

Nunan, D. (2004). Task-based language teaching. Cambridge: Cambridge 
University Press.

Radzi, A. H. M., Azmin, A. M, Zolhani, N. H., \& Latif, S. A. (2007). Adopting communicative language teaching (CLT) approach to enhance oral competencies among students: Teachers' attitudes and beliefs. Malaysia: Faculty of Communication and Modern Languages, Universiti Utara Malaysia.

Rahmawati, Y. (2019). Teachers' voices on the challenges of the implementation of communicative approach in regards to the 2013 curriculum. Indonesian Journal of English Education, 6(1), 65-78. DOI: 10.15408/ijee.v6i1.12761

Richards, J. C. (2001). Curriculum development in language teaching. Cambridge: Cambridge University Press.

Richards, J. C. (2006). Communicative language teaching today. Cambridge: Cambridge University Press. 